\title{
KARAKTERISTIK LAHAN DAN KONSTRUKSI TABEL KEBUTUHANNYA BAGI PENGEMBANGAN ATUNG (Parinarium glaberimum Hassk) DI NEGERI HARUKU
}

\author{
Land Characteristics and the Construction Need Tables for Development of Atung \\ (Parinarium glaberimum Hassk) in Haruku Village
}

\section{Magdalena V. Ferdinandus ${ }^{1}$, Conradus Ufie ${ }^{2, *}$, Simson Liubana $^{2}$}

\author{
${ }^{1}$ Program Studi Agroekoteknologi, Jurusan Budidaya Pertanian, Fakultas Pertanian, Universitas Pattimura \\ ${ }^{2}$ Jurusan Budidaya Pertanian, Fakultas Pertanian, Universitas Pattimura \\ Jl. Ir. M. Putuhena, Kampus Poka, Ambon 97233 \\ *Penulis korespondensi: E-mail: conradus.ufie@faperta.unpatti.ac.id
}

\begin{abstract}
This research was conducted on sample area where Atung plant grow, focused on the Land "Petuanan" of Haruku village in Haruku small Island-Central Maluku Regency, from December 2016 till May 2017. The aims of this research were: 1) to assess the physical characteristics of land affecting the growth and production of Atung plant at the study area; 2) to elaborate the physical essential information and necessary data on the basis of literature and field review in constructing the land suitability table for the Atung Plant (as a preliminary approach); 3) to implement or test the appropriate land suitability table for the land suitability evaluation of Atung based on available biophysical land characteristic data. The method used in this study was a library study and field survey using the distance of flexible transect observation in accordance with the conditions where Atung grows. The results of this study consisted of the land characteristics data for Atung plant; i.e. climate, topography, and soil. The study of land characteristics obtained from the literature, field review and knowledge of the local community and construction of the land suitability table for Atung, an appropriate test in the Waai village showed that the land suitability category as the S3 class with the limiting factor was $\mathrm{pH}$ value that was easily improved and upgraded to the suitability class of S2/S1.
\end{abstract}

Keywords: Atung, land suitability table, physical land characteristics

\section{ABSTRAK}

Penelitian ini dilaksanakan pada satu area sampel yang ditumbuhi Atung secara terfokus pada lahan petuanan Negeri Haruku di pulau kecil Haruku Kabupaten Maluku Tenggah, dari bulan Desember 2016 - Mei 2017. Tujuan penelitian: 1) mengkaji karakteristik fisik lahan yang mempengaruhi pertumbuhan dan produksi Tanaman Atung di lokasi penelitian; 2) merangkum informasi dan data kerakteristik fisik lahan esensial yang perlu berdasarkan tinjauan literatur dan lapangan dalam mengkonstruksi tabel kesesuaian lahan untuk Tanaman Atung (sebagai pendekatan awal); 3) menerapkan atau menguji coba tabel kesesuaian lahan tersebut guna dalam mengevaluasi kesesuaian lahan bagi tanaman Atung berdasarkan data karakteristik lahan biofisik yang telah tersedia. Metode yang digunakan dalam penelitian ini adalah Studi pustaka dan Survei Lapangan secara partisipatif, dengan menggunakan jarak observasi transek secara fleksibel sesuai tempat tumbuh Atung. Hasil penelitian ini meliputi data karakteristik lahan untuk tanaman Atung berupa iklim, topografi, dan tanah. Kajian karakteristik lahan dari data literatur dan tinjauan lapangan serta pengetahuan lokal masyarakat, dan konstruksi tabel kesesuaian lahan Atung, berikut dari hasil uji coba di desa Waai menunjukan bahwa kelas kesesuaian tergolong kelas S3 dengan faktor pembatas ringan yakni pH yang dapat diatasi dalam menaikan peringkat ke S2/S1.

Kata kunci: Atung, karakteristik fisik lahan, tabel kesesuaian lahan

\section{PENDAHULUAN}

Maluku adalah sebuah provinsi kepulauan yang berada di kawasan Timur Indonesia, dengan keragaman spesies cukup tinggi baik flora maupun fauna, serta belum termanfaatkan sebagaimana mestinya. Tersusun dari pulau-pulau kecil dan sedang dengan kondisi iklim dan tanah bervariasi, maka lingkungan kepulauan Maluku berpotensi bagi proses pembentukan keragaman spesis tumbuhan dengan tingkat endemisitas yang tinggi. Potensi tersebut meliputi berbagai manfaat yang di miliki dalam mendukung kenyamanan hidup pada masingmasing pulau dan gugus pulau yang ada, baik di bidang 
pertanian-perikanan pesisir dan bidang-bidang lain, seperti halnya Atung (Parinarium glaberimum Hassk).

Secara umum Atung terdapat hampir di semua tempat di Provinsi Maluku terutama di daerah Maluku Tengah (Moniharapon 1998). Tanaman ini kelihatan tumbuh alami pada wilayah pesisir pulau hingga wilayah berbukit/bergunung di daerah belakang (pertengahan) pulau. Biasanya masyarakat di wilayah Maluku Tengah menggunakan buah/biji Atung secara arif (kearifan lokal) sebagai pengawet bahan pangan/makanan alami, juga dipakai sebagai bahan obat-obatan maupun pengawet kayu secara tradisional.

Pulau Haruku adalah sebuah pulau kecil di Kabupaten Maluku Tengah, yang dihuni oleh penduduk atau masyarakat pada sebelas desa. Masyarakat pada pulau Haruku, juga mengenal dan memanfaatkan Atung secara tradisional. Belakangan, kearifan lokal masyarakat dalam mendayagunakan Atung ini, banyak diteliti secara ilmiah dan dikembangkan secara moderenuniversal sebagai pengawet pangan alami/organik, dan direkomendasikan pengembangan budidayanya guna menunjang agro industri rakyat (usaha pertanian masyarakat) wilayah pesisir dan pulau-pulau kecil di Maluku. Namun sampai saat ini tanaman ini belum dilakukan pengembangan seperti budidaya tanaman, walaupun sudah ada beberapa penelitian yang menunjukan bahwa prospek tumbuhan ini sebagai bahan pengawet bagi makanan, sehingga dapat digunakan untuk mengganti bahan pengawet buatan, dimana salah satu penyebabnya adalah ketiadaan "Syarat Tumbuh Tanaman Atung" yang biasanya digunakan sebagai dasar evaluasi lahan bagi pengembangannya.

Penelitian ini bertujuan untuk: 1) Mengkaji karakteristik fisik lahan yang mempengaruhi pertumbuhan dan produksi Tanaman Atung di lokasi penelitian; 2) Merangkum informasi dan data kerakteristik fisik lahan esensial yang perlu berdasarkan tinjauan literatur dan lapangan dalam mengkonstruksi tabel kesesuaian lahan untuk tanaman Atung (sebagai pendekatan awal); dan 3) Menerapkan atau menguji coba tabel kesesuaian lahan tersebut guna dalam mengevaluasi kesesuaian lahan bagi tanaman Atung berdasarkan data karakteristik lahan biofisik yang telah tersedia.

\section{METODE PENELITIAN}

\section{Tempat dan Waktu Penelitian}

Penelitian ini dilaksanakan pada satu sampel area (cross section) dari lahan petuanan Negeri Haruku secara terfokus di Pulau Haruku Kabupaten Maluku Tenggah, dari bulan Desember 2016 - Mei 2017.

\section{Alat dan Bahan}

Alat dan bahan yang digunakan dalam penelitian ini adalah Peta lokasi (peta pulau Haruku), Buku Munsel, Auger (Bor), Pisau Lapang, Pacul., GPS, Abney level, Altimeter, Meter roll, Buku catatan lapangan, Kamera, kuisioner, Kertas pH, Aquades, $\mathrm{H}_{2} \mathrm{O}_{2}$ (15-20\%), HCL $(1 \mathrm{~N})$, Guide Line For Soil Profile Description, Kebutuhan P3K sederhana.

\section{Metode Penelitian}

Adapun metode yang digunakan dalam penelitian ini adalah Studi pustaka dan Survei Lapangan secara partisipasif, dengan menggunakan jarak observasi transek secara fleksibel sesuai tempat tumbuh Atung.

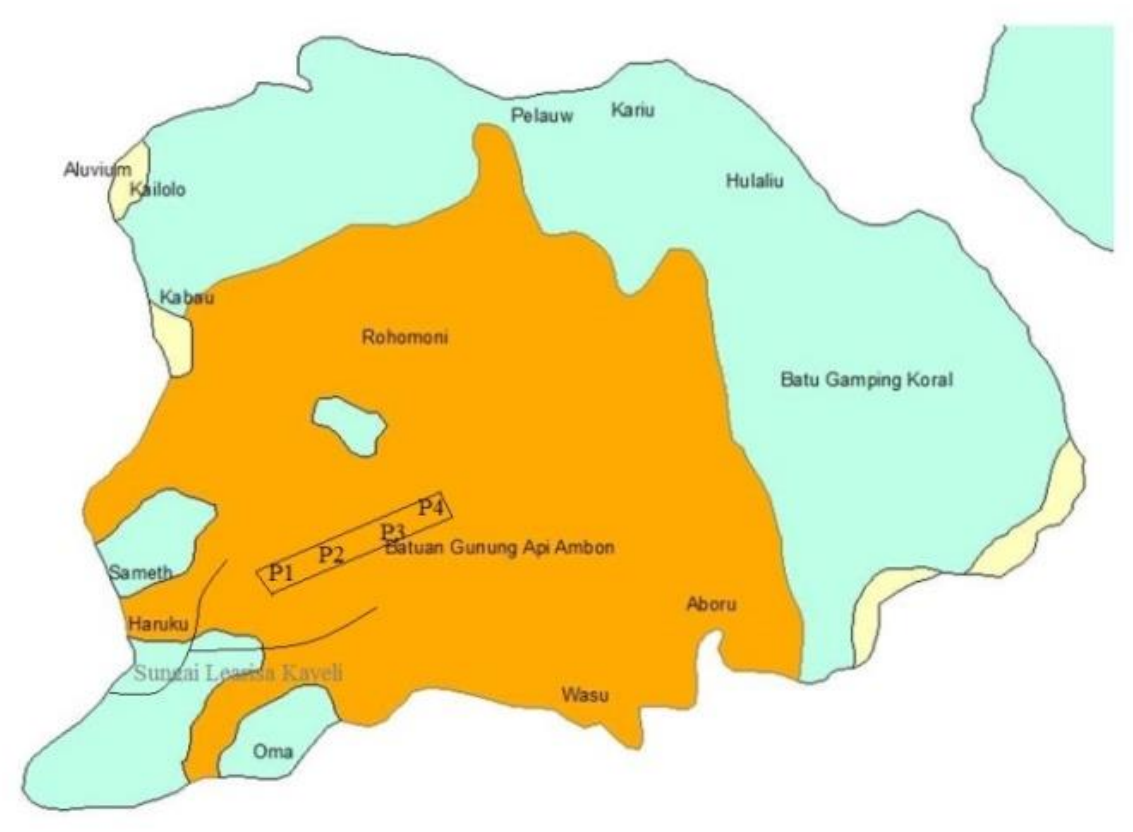

Gambar.1. Peta Situasi dan Geologi Pulau Haruku 


\section{HASIL DAN PEMBAHASAN}

\section{Gambaran Umum Daerah Penelitian}

Secara Astronomi, Negeri Haruku di Pulau Haruku memiliki batas-batas wilayah sebagai berikut: Sebelah Utara berbatasan dengan Negeri Rohomoni, Sebelah Selatan berbatasan dengan Negeri Oma, Sebelah Barat berbatasan dengan Laut, Sebelah Timur berbatasan dengan Negeri Aboru.

\section{Karakteristik Lahan Pendukung Pertumbuhan dan Produksi Tanaman Atung di Wilayah Pesisir Rumahtiga Pulau Ambon}

Berdasarkan orientasi lapangan yang penulis lakukan tentang kondisi lahan tempat tumbuh tanaman Atung di lokasi kampus Unpatti poka, dapat disimpulkan bahwa tanaman Atung cenderung tumbuh optimal pada wilayah pesisir dengan jenis tanah Regosol halus berwarna hitam hingga agak kekuningan ke dalam tanah (pengaruh warna pasir halus), dengan kondisi iklim yang di bagi menjadi 3 bagian yaitu: curah hujan $3725 \mathrm{~mm}$, temperatur $24,2^{\circ} \mathrm{c}$, kelembaban $78 \%$. Kondisi Fisiografi untuk ketinggian $8 \mathrm{mdpl}$, lereng 2\%(datar), untuk kondisi tanahnya kedalaman $>100 \mathrm{~cm}$, tekstur pasir berlempung, lempung berdebu, pasir, struktur lepas atau gembur, serta drainase tanahnya baik. Pada studi awal ini, jumlah buah Atung (Gambar 1) per pohon berkisar 83 buah, bahkan ada tiga buah yang telah jatuh atau gugur secara alamiah.

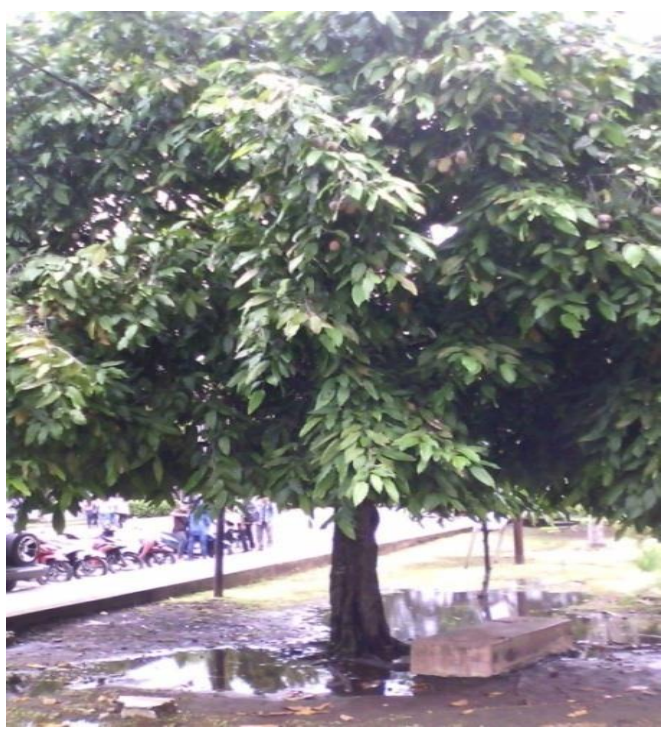

Gambar 1. Contoh Pertumbuhan dan Produksi Tanaman Atung pada Lokasi Kampus Unpatti

\section{Karakteristik Fisik Lahan yang Mempengaruhi} Pertumbuhan/Produksi Tanaman Atung

\section{Informasi Umum Tentang Pertumbuhan Dan Manfaat Atung di Lokasi Penelitian}

Umumnya masyarakat Haruku mengenal Atung dengan istilah Atong. Berdasarkan hasil wawancara dari masyarakat maupun dari petani sekitar lokasi penelitian (sampel area) baik itu di lapangan maupun di Desa, tanaman Atung tumbuh baik di daerah pengununngan atau daerah yang tinggi, yang warna tanahnya hitam (Ume Meteh) dan biasanya tumbuh sendiri/alami di dalam dusung.

Tanaman Atung dikenal dengan 2 jenis Tanaman yaitu Atung Darat dan Atung Laut, untuk Atung Darat yaitu Atung yang biasanya digunakan untuk sasi lompa dan kebutuhan lainnya. Ciri-ciri dari Atung darat adalah pohonya tidak terlalu besar, buahnya berwarna coklat bata dengan kulit buah yang keras dan biji buah yang berwarna keabuan sampai coklat tua. Sedangkan untuk Atung Laut hanya digunakan untuk kayu bakar saja dan buahnya itu tidak dapat dimakan. Ciri-ciri Atung Laut ini adalah memiliki pohon yang besar dan buahnya hitam. Atung sangat sulit untuk mati sendiri kecuali ditebang walaupun begitu patut disayangkan karena keberadaan Atung Laut yang sifatnya endemik ini telah punah menurut informasi masyarakat. Atung biasanya digunakan oleh masyarakat Haruku secara lokal untuk bahan makanan dan obat.

\section{Kondisi Karakteristik Lahan}

Data dan informasi karakteristik lahan yang dapat diamati, dari empat profil yang dideskripsi pada area sampel merupakan tanah Kambisol (lihat cross section pada Gambar 2).

Profil Pewakil 1. Pada ketinggian $89 \mathrm{mdpl}$ dengan kondisi kemiringan lereng 0-3\% pada daerah datar, penggunaan lahan kebun campuran (pola dusung), vegetasi dominan cengkih dan nenas. Tekstur tanahnya lempung, lempung liat berdebu, dan lempung berliat, dengan struktur tanah gumpal membulat dan $\mathrm{pH}$ tanah berkisar dari 5,5-4,5

Profil pewakil 2. Pada ketinggian $139 \mathrm{mdpl}$ dengan kondisi kemiringan lereng 3-8\% pada daerah landai, penggunaan lahan kebun campuran (pola dusung), vegetasi dominan bambu dan singkong. Tekstur tanahnya liat berdebu, lempung liat berpasir dan lempung berliat, dengan struktur tanah remah dan gumpal bersudut dan $\mathrm{pH}$ tanah berkisar dari 5-4,5.

Profil pewakil 3. Pada ketinggian $134 \mathrm{mdpl}$ dengan kondisi kemiringan lereng $30-45 \%$ pada daerah curam bentuk cekungan. Untuk kondisi kemiringan lereng seperti ini sebaiknya dilakukan tindakan konservasi secara alami. Dalam hal ini jika ada tumbuhan yang sudah bertumbuh di lereng sebaiknya tetap dibiarkan saja, ataukah jika ada tanaman yang berbuah kemudian buahnya itu jatuh sehingga mengeluarkan tunas baru maka dibiarkan saja tunas tersebut tumbuh menjadi tanaman dewasa. Penggunaan lahan kebun campuran (pola dusung), vegetasi dominan cengkih. Tekstur tanahnya lempung, lempung liat dan lempung berpasir, dengan struktur tanah remah dan gumpal membulat dan $\mathrm{pH}$ tanah berkisar dari 5,5-4. 


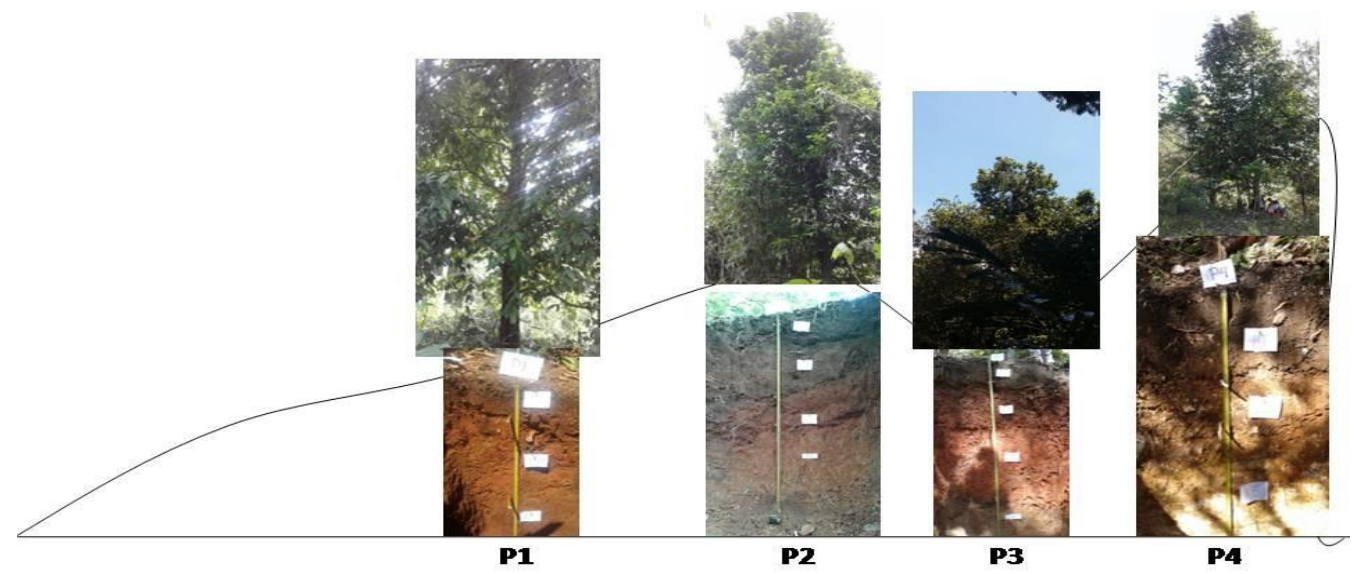

Gambar 2. Penampang melintang (cross section) dari lokasi penelitian yang mengidentifikasi posisi pertumbuhan atung, posisi profil pewakil, bentuk lereng dan batuan/bahan induk secara umum

Profil pewakil 4. Pada ketinggian $211 \mathrm{mdpl}$ dengan kondisi kemiringan lereng $15-30 \%$ pada daerah agak curam, untuk kemiringan lereng seperti ini sebaiknya dilakukan tindakan konservasi secara alami. Penggunaan lahan kebun campuran (pola dusung), vegetasi dominan cengkih. Tekstur tanahnya lempung berdebu dan lempung liat berdebu, dengan struktur tanah remah, gumpal bersudut dan gumpal membulat dan $\mathrm{pH}$ tanah berkisar dari 5,5-4,5.

\section{Konstruksi Tabel Kesesuaian Untuk Atung: Pendekatan Awal \\ Telah dikemukakan pada bagian pendahuluan} bahwa kearifan lokal masyarakat Maluku termasuk Haruku dalam mendayagunakan Atung sebagai pengawet alami tradisional setempat, kini telah banyak diteliti dan dikembangkan secara moderen-universal sebagai pengawet pangan organik. Hal ini menjadi dasar dalam merekomendasikan pengembangan budidaya guna menunjang agro industri rakyat (usaha pertanian rakyat) wilayah pesisir dan pulau-pulau kecil/sedang di Maluku. Beberapa diantaranya seperti yang diteliti dan direkomendasi oleh Moniharapon (1998, 2006). Namun demikian pembudidayaan Atung tersebut belum terlaksana seperti yang diharapkan, dimana salah satu penyebabnya adalah ketiadaan "Syarat Tumbuh/Kesesuaian Tanaman Atung" yang biasanya digunakan sebagai dasar/kunci evaluasi kesesuaian lahan bagi pengembangan budidaya secara optimal dan lestari atau berkelanjutan (sustainiable development).

Berdasarkan uraian di atas, maka salah satu tujuan penelitian yang ingin di capai adalah mencoba untuk mengkonstruksi satu tabel kesesuaian lahan sederhana untuk Atung. Sebagai suatu pendekatan awal, dengan merangkum/mengawinkan informasi dan data karakteristik fisik lahan esensial yang relevan berdasarkan "tinjauan literatur" dan "kajian lapangan" pada area sampel di lokasi penelitian. Walaupun kajian ini mengutamakan karakteristik fisik lahan, namun kajian sosial-budaya terkait kearifan lokal tentang hubungan karakteristik fisik lahan petuanan setempat dengan kesesuaian pertumbuhan dan produksi secara alami tiap tahun juga dilakukan, termasuk kecenderungan iklim lokal setempat mengingat data iklim yang digunakan berasal dari stasiun di AmahaiMasohi yang jauh dari Negeri Haruku.

Sys et al. (1993) menegaskan bahwa konstruksi tabel kebutuhan tanaman (the crop requirements) dapat diringkas dalam tabel terpisah untuk kondisi iklim dan tanah mencakup topografi (landscape). Untuk setiap karakteristik lahan tersebut diindikasikan untuk empat level limitasi dengan kelas kesesuaian lahannya $(\mathrm{S} 1, \mathrm{~S} 2, \mathrm{~S} 3, \mathrm{~N})$. Dengan catatan untuk tanaman-tanaman (tumbuhan) tertentu tabel tersebut dielaborasi (dikontekstualisasi) berdasarkan ketersediaan data pada literatur dan laporan-laporan teknis. Sedangkan untuk tanaman-tanaman lain dapat diadaptasi untuk kondisikondisi lapangan spesifik berdasarkan pengalaman regional/lokal setempat (termasuk kearifan lokal atau pengetahuan tradisonal para petani). Disamping itu bahwa fungsi-fungsi produksi (untuk suatu tanaman atau tumbuhan) dapat bekerja atau berfungsi memadai pada suatu wilayah/lokasi dapat saja tidak memadai/cocok pada wilayah lain. Oleh karena itu tabel-tabel kebutuhan pertumbuhan/produksi tanaman yang telah ada maupun baru dikonstruksi, hendaknya dipertimbangkan sebagai suatu pedoman umum dimana level-level limitasi untuk karakteristik yang cenderung berbeda (misalnya pada Tabel Kesesuaian lahan dinyatakan tidak sesuai: S3-N sedangkan di lapangan tanaman/tumbuhannya tumbuh subur dan sarat produksi. Bila dicermati dari jaman leluhur ratusan-ribuan tahun hendaknya ditinjau ulang secara kritis dan diadaptasi .

sesuai kondisi-kondisi lokal bahkan menurut varietas tanaman yang dikaji pengembangan atau perkebunannya. Seperti yang dilakukan Ufie (1993) dalam kajian lahan bagi kultivasi "Pisang Cavendis" berorientasi ekspor pada kaki Gunung Cameroon.

Ringkasan data dan informasi karakteristik fisik lahan yang relevan untuk Atung berdasarkan tinjauan literatur dan kajian lapangan disajikan pada Tabel 1 . Sedangkan upaya penulis untuk mengkonstruksi suatu Tabel Kesesuaian Lahan untuk pertumbuhan/produksi 
dan budidaya Atung sebagai suatu pendekatan awal disajikan pada Tabel 2.

\section{Uji Coba Penerapan Tabel Kesesuaian Lahan Yang Dikontruksi Dalam Mengevaluasi Kesesuaian Lahan Bagi Atung di Waai Pulau Ambon}

Untuk mengetahui seberapa jauh efektifitas dari tabel kesesuaian lahan sederhana untuk Atung yang dikonstruksi (sebagai suatu pendekatan awal), maka konstruksi tabel kesesuaian lahan sederhana ini diuji coba penerapannya dalam mengevaluasi kesesuaian lahan bagi pengembangan/budidaya Atung berdasarkan (menggunakan) data karakteristik biofisik lahan yang telah tersedia. Dengan merujuk pada data jenis tanah Kambisol (Distrik) yang diperoleh di lokasi penelitian Negeri Haruku menurut sistem PPT (2014), atau Ume Kau (tanah merah) dan Ume Meteh (tanah hitam) menurut penamaan/istilah atau terminologi lokal masyarakat Negeri Haruku; maka data tanah yang digunakan dalam uji coba ini adalah Kambisol Distrik pada lokasi kampung Ujung Batu-Desa Waai Pulau Ambon (ISRIC, 1994).

Data Karakteristik Fisik Lahan Kampung ujung Batu-Desa Waai Pulau Ambon

Lokasi Profil Tanah : Pada Latitude 03\%41'0''S Longitude $128^{\circ} 17^{\prime} 0^{\prime \prime} \mathrm{E}$

Deskriptor : Van den Born (Februari, 1989)

Klasifikasi FAO (1988) : Dystric Cambisol

Posisi Profil Tanah : pada puncak lereng

Pada ketinggian 60 mdpl dengan kondisi kemiringan lereng 4\%,bentuk cembung. Tekstur tanahnya lempung berdebu, dengan struktur tanah gumpal membulat dan $\mathrm{pH}$ tanah berkisar dari 5-4,0, kedalaman tanahnya $107 \mathrm{~cm}$

Tabel 1. Ringkasan Dari Karakteristik Iklim, Topografi, Dan Tanah Yang Dibutuhkan Bagi Pertumbuhan/Produksi Dan Kultivasi/Budidaya Atung Berdasarkan Tinjauan Literatur Dan Kajian Kondisi Lahan Di Lokasi Penelitian

\begin{tabular}{|c|c|c|c|c|c|c|}
\hline \multirow{2}{*}{$\begin{array}{c}\text { Karakteristik } \\
\text { Fisik Lahan }\end{array}$} & \multicolumn{3}{|c|}{ Indikasi Kebutuhan } & \multirow[t]{2}{*}{ Sumber } & \multicolumn{2}{|c|}{ Kondisi di Lokasi Penelitian } \\
\hline & Umum & Optimum & Marginal & & $\begin{array}{c}\text { Data Fisik } \\
\text { Lahan }\end{array}$ & Pengetahuan Lokal Masyarakat \\
\hline $\begin{array}{l}\text { Iklim } \\
\text { Curah hujan }(\mathrm{mm}) \\
\text { Kelembaban }(\%) \\
\text { Temperatur }\left({ }^{\circ} \mathrm{C}\right) \\
\text { Penyinaran } \\
\text { (radiasi) }\end{array}$ & $\begin{array}{l}\cdots \cdots \\
\cdots \cdots \\
\cdots \cdots \\
\cdots\end{array}$ & $\begin{array}{c}1500-3500 \\
80-90 \\
21-30 \\
\text { sangat butuh cahaya }\end{array}$ & $\begin{array}{c}\ldots . . \\
\ldots . . \\
\ldots . . \\
\text { Di bawah } \\
\text { tegakan lain }\end{array}$ & $\begin{array}{l}a, b \\
a, b \\
a, b \\
a, b\end{array}$ & $\begin{array}{c}2000-3000 \\
80-90 \\
27-30\end{array}$ & $\begin{array}{l}\text { Curah hujan terjadi pada Mei - } \\
\text { oktober tiap tahun. } \\
\text { Atung biasanya tumbuh pada lahan } \\
\text { petuanan yang datar - curam; warna } \\
\text { tanahnya hitam (Ume Meteh), ada } \\
\text { pula yang tanahnya merah (Ume } \\
\text { Kau). Buah Atung sangat banyak } \\
\text { pada tanah pertama berikutnya yang } \\
\text { kedua, dimana proses pembungaan } \\
\text { dari bulan Desember -Januari; dan } \\
\text { proses pembuahan dari bulan } \\
\text { September - Desember pada bulan } \\
\text { Oktober buah Atung sangat banyak. }\end{array}$ \\
\hline
\end{tabular}

\begin{tabular}{|c|c|c|c|c|c|}
\hline \multicolumn{6}{|l|}{ Topografi } \\
\hline Lereng $(\%)$ & $>3-40$ & $\ldots$. & $\ldots \ldots$ & $\mathrm{a}, \mathrm{b}, \mathrm{c}$ & $\begin{array}{c}0-8(\mathrm{P} 1 \& \mathrm{P} 2) \\
15-45(\mathrm{P} 4 \& \mathrm{P} 3)\end{array}$ \\
\hline Bentuk lereng & $\begin{array}{l}\text { datar- } \\
\text { agak }\end{array}$ & $\ldots$. & $\ldots \ldots$ & & Datar-curam \\
\hline $\begin{array}{c}\text { Ketingian dari } \\
\text { muka laut }(\mathrm{m})\end{array}$ & curam & $0-300$ & & $\mathrm{a}, \mathrm{b}, \mathrm{c}$ & $89-211$ \\
\hline \multicolumn{6}{|l|}{ Tanah } \\
\hline Kedalaman(cm) & dalam & $\quad \ldots .$. & $\ldots \ldots$ & $\ldots .$. & $105-170$ \\
\hline Tekstur & $\ldots .$. & $\begin{array}{l}\text { lempung berpasir - } \\
\text { liat berlempung }\end{array}$ & $\ldots$. & $\mathrm{a}, \mathrm{b}$ & $\begin{array}{c}\text { Lempung liat } \\
\text { berpasir- } \\
\text { lempung liat }\end{array}$ \\
\hline Struktur & $\ldots .$. & remah/gembur & $\ldots .$. & $a, b$ & berdebu \\
\hline $\mathrm{pH}$ & Cukup & $6,0-6,5$ & $\ldots$. & $a, b$ & Remah-gumpal \\
\hline Drainase & hara & harus baik & tergenang > & $a, b$ & 4,5-5,5 \\
\hline
\end{tabular}

Keterangan : a = Matinahoru ( 2007); b = BPTP Ambon (2011); c = Moniharapon (1998) 
Tabel 2. Konstruksi Tabel Kebutuhan Karakteristik Fisik Lahan Yang Sesuai (Tabel Kesesuaian Lahan) Bagi Pertumbuhan/Produksi Atung Dan Budidayanya

\begin{tabular}{|c|c|c|c|c|}
\hline \multirow[t]{2}{*}{ Karakteristik fisik lahan } & \multicolumn{4}{|c|}{ Peringkat/kelas kesesuaian lahan } \\
\hline & S1 & S2 & S3 & $\mathbf{N}$ \\
\hline \multicolumn{5}{|l|}{ IKLIM } \\
\hline \multirow[t]{2}{*}{ Curah hujan(mm) } & $2000-3000$ & $3000-35000$ & $3500-4000$ & $>4000$ \\
\hline & & $1500-2000$ & $1000-1500$ & $<1000$ \\
\hline \multirow{2}{*}{ Temperatur $\left({ }^{\circ} \mathrm{C}\right)$} & $25-30$ & $30-35$ & $35-40$ & $>40$ \\
\hline & & $20-25$ & $15-20$ & $<15$ \\
\hline \multirow[t]{2}{*}{ Kelembaban $(\%)$} & $80-90$ & $90-95$ & $95-100$ & $>100$ \\
\hline & & $75-80$ & $70-75$ & $<70$ \\
\hline \multicolumn{5}{|l|}{ TOPOGRAFI } \\
\hline Lereng $(\%)$ & $0-15$ & $15-45$ & $45-75$ & $>75$ \\
\hline Bentuk lereng & datar-bergelombang & $\begin{array}{l}\text { bergelombang- } \\
\text { curam } \\
0-5\end{array}$ & $\begin{array}{l}\text { Curam-sangat } \\
\text { curam }\end{array}$ & $\begin{array}{l}\text { Ekstrim } \\
\text { curam } \\
>300\end{array}$ \\
\hline $\begin{array}{l}\text { Ketinggian muka } \\
\text { laut }(\mathrm{m})\end{array}$ & $5-75$ & $75-150$ & $150-300$ & \\
\hline \multicolumn{5}{|l|}{ TANAH } \\
\hline Kedalaman $(\mathrm{cm})$ & $50->100$ & $35-50$ & 20-35 & $<20$ \\
\hline Tekstur & $\begin{array}{l}\text { Lempung berdebu } \\
\text { Lempung berpasir } \\
\text { Pasir berlempung }\end{array}$ & $\begin{array}{l}\text { Liat berlempung } \\
\text { Lempung berliat }\end{array}$ & Liat berdebu & Liat \\
\hline \multirow[t]{2}{*}{ Stuktur } & Remah & Gumpal & Gumpal & Tiang \\
\hline & Granular & Membulat & bersudut & Prisma \\
\hline \multirow[t]{2}{*}{$\mathrm{pH}$} & & $5,0-5,5$ & $4,0-5,0$ & $<4,0$ \\
\hline & $5,5-6,0$ & $6,0-6,5$ & $6,5-7,0$ & $>7,0$ \\
\hline Drainase & Baik & Agak baik & Buruk & $\begin{array}{c}\text { Buruk sekali } \\
\text { (tergenang }>7 \\
\text { hari) }\end{array}$ \\
\hline
\end{tabular}

Tabel 3. Kesesuaian Lahan Tanaman Atung di Desa Ujung Batu Waai Pulau Ambon

\begin{tabular}{|c|c|c|c|c|}
\hline \multirow{2}{*}{ Karakteristik fisik lahan } & \multicolumn{4}{|c|}{$\begin{array}{l}\text { Peringkat/kelas } \\
\text { kesesuaian lahan }\end{array}$} \\
\hline & S1 & S2 & S3 & $\mathbf{N}$ \\
\hline \multicolumn{5}{|l|}{ IKLIM } \\
\hline Curah hujan (mm) & \multicolumn{4}{|c|}{$\checkmark$} \\
\hline Temperatur $\left({ }^{\circ} \mathrm{C}\right)$ & \multicolumn{4}{|c|}{$\checkmark$} \\
\hline Kelembaban (\%) & \multicolumn{4}{|c|}{$\checkmark$} \\
\hline \multicolumn{5}{|l|}{ TOPOGRAFI } \\
\hline Lereng $(\%)$ & \multicolumn{4}{|c|}{$\checkmark$} \\
\hline Bentuk lereng & \multicolumn{4}{|c|}{$\checkmark$} \\
\hline $\begin{array}{l}\text { Ketinggian muka } \\
\text { laut }(\mathrm{m})\end{array}$ & \multicolumn{4}{|c|}{$\checkmark$} \\
\hline \multicolumn{5}{|l|}{ TANAH } \\
\hline Kedalaman(cm) & & & & \\
\hline Tekstur & & & & \\
\hline Stuktur & \multicolumn{4}{|c|}{$\checkmark$} \\
\hline $\mathrm{pH}$ & \multicolumn{4}{|c|}{$\checkmark$} \\
\hline Drainase & & & & \\
\hline
\end{tabular}

Hasil uji coba penerapan tabel kesesuaian lahan sederhana untuk Atung yang dikonstruksi sebagai suatu pendekatan awal (Tabel 3.2) dengan mencocokan (matching) kondisi karakteristik biofisik lokasi (Ujung Batu Desa Waai), menunjukan bahwa tanah/lahan di kampung Ujung Batu-Desa Waai Pulau Ambon adalah sangat sesuai (S1) untuk iklim dan topografi dengan kondisi curah hujan 2000-3000 mm, 25-30 $\mathrm{C}$ (suhu) dan 80-90\% (kelembaban). Dengan kemiringan lerengnya 0$15 \%$ bentuk lereng datar-curam dan tinggi dari muka laut 5-75m. Untuk kondisi tanahnya kedalaman 50->100m, tekstur lempung berdebu, lempung berpasir, pasir berlempung, dan drainase baik masuk pada kelas sangat sesuai (S1) sedangkan untuk struktur gumpal membulat jatuh pada kelas cukup sesuai (S2) dan untuk pH 4,0-5,0 jatuh pada kelas sesuai maginal (S3) untuk pengembangan/budidaya Atung ke depan.

Faktor pembatas yang menentukan kelas kesesuaian S3nr adalah faktor pH 4,25 sesuai marginal (S3) yang menunjukkan bahwa bila faktor ini diatasi dengan cara pemberian bahan organik atau dengan cara pengapuran maka kelas kesesuaiannya akan menjadi S2 atau bahkan S1. Hal ini sejalan dengan realita lapangan yang nampak bahwa beberapa Atung yang tumbuh alami 
di lahan desa Waai sangat subur dan rimbun serta banyak sekali buahnya.

\section{KESIMPULAN}

Metode yang diterapkan dalam penelitian ini berhasil mengkonstruksi suatu " Tabel Kesesuaian Lahan untuk Atung" (sebagai pendekatan awal) di bawah kondisi manajemen pertanian masyarakat pesisir yang sederhana/alamiah di Negeri Haruku. Identifikasi faktorfaktor karakteristik fisik lahan yang mempengaruhi/ membatasi pertumbuhan dan produksi tanaman/ tumbuhan Atung pada tabel yang dikonstruksi untuk Haruku dan uji coba penerapannya di lahan Desa Waai pulau Ambon, dapat dibuat beberapa kesimpulan: 1) Karakteristik fisik lahan yang mempengaruhi pertumbuhan dan produksi Atung adalah iklim, topografi, dan tanah. Dua yang terakhir ini dapat dideskripsi di lapangan secara baik; 2) kajian karakteristik lahan di lapangan dapat dilengkapi dengan kajian pengetahuan lokal dari masyarakat setempat; dan 3) hasil uji coba tabel kesesuaian lahan untuk Atung yang dikonstruksi di kampung Ujung Batu-desa Waai menunjukan kelas kesesuaian sangat sesuai sampai sesuai atau sesuai marginal (S1-S2/S3), dengan faktor pembatas $\mathrm{S} 3 \mathrm{nr}$ adalah faktor $\mathrm{pH} 4,25$.

\section{DAFTAR PUSTAKA}

Anonimous, 1988. RePPRot, Peta Land Sistem/Land Suitability Skala 1: 250.000, sheet 2.612.
ISRIC. 1994. Soil Reference Profiles Of Indonesia: Field and Analytical Data. Center For Soil and Agroclimatic Research-International Soil Reference and Information Centre.

Matinahoru, J.M. 2007. Beberapa aspek botani, ekologi dan silvikultur tumbuhan Atong (Parinarium glaberimmum Hassk). Jurnal Agroforestri 2: 243246.

Moniharapon, T. 1998. Kajian Fraksi Bioaktif Atung Sebagai Bahan Pengawet Pangan. Disertasi. Program Studi Ilmu Pangan. Program Pascasarjana IPB, Bogor.

Moniharapon, T. 2006. Atung Dan Sumberdaya Pangan Lokal Untuk Pembangunan Industri Dan Pengembangan Ekonomi Maluku. Pidato Pengukuhan Guru Besar Pada Fakultas Perikanan dan Ilmu Kelautan UNPATTI 21 Januari 2006.

Ruhukail, N.L. 2007. Karakteristik tanah dan klasifikasinya di Desa Haruku Kabupaten Maluku Tengah. Jurnal Agroforestri 2: 322-328.

Sys, C., E. Van Ranst, J. Debaveye, and F. Beernaert, F. 1993. Land Evaluation Part III: Crop requirements. Agricultural Publication No.7.

Ufie, C. 1993. Land Assesment For Banana (Musa spp) Cultivation On The Eastern Footslope Of Mount Cameroon. Unpublished Thesis ITC for PostGraduate Soil Scientist, Geologic and Soil Science Department, Faculty of Science, University of Ghent-Belgium.

BВPPTP Ambon. 2011. http://ditjenbun.pertanian.go.id/b bpptpambon/berita-303-berbagai-manfaat-buahatung.html. tangal kunjung 15 oktober 2015. 